\title{
CONSUMER BEHAVIOUR MANAGEMENT FEASIBILITY STUDY IN THE CULTURAL AND CREATIVE INDUSTRY: THE CASE OF 'THE EMBASSY OF LATGALE “GORS”'
}

\author{
Elza JURANE
}

\author{
Mg. soc. sc., the Embassy of Latgale 'GORS', Rezekne, Latvia \\ e-mail: elza.jurane@gmail.com, phone: +371 26141048
}

\begin{abstract}
The number of cultural institutions has increased in recent years. The range of cultural events offered is so varied that cultural institutions often have problems to choose the most suitable marketing techniques in order to successfully compete in the saturated market and attract new customers. Since 2013 in Latvia three new concert halls have been built and a number of cultural centers have been renovated, therefore it is necessary to seek for new ways to act on the consumer and acquire that part of the public that have not attended cultural institutions or do it very rarely. The aim of the research is to explore possibilities on how to manage consumer behavior-influencing factors when choosing cultural event offers. The following primary research methods are used: the monographic or descriptive research method, the Statistical Package for the Social Sciences (SPSS) processing method, the deductive method, evaluation and analysis of surveys, graphical analysis and synthesis. The key results are: a survey of consumer behavior - influencing factors of cultural event attendance by generations in the Embassy of Latgale "GORS". Consumer behavior influencing factors by generations in the Embassy of Latgale "GORS" needs to be realized in order to attract new customers.
\end{abstract}

Keywords: consumer behavior, consumer behavior - influencing factors, cultural economics, generations

JEL code: Z190, M110, M390, L780, R320

\section{Introduction}

There is a growing interest in a variety of cultural events and role of cultural event attendance as a kind of spending leisure time. Cultural event attendance became not only a leisure activity but also a meeting place and an opportunity to socialize. In order to be able to offer a high-quality programme of cultural events, a consumer behaviour research needs to be realized, which will allow cultural institutions to offer more appropriate products to meet consumer needs.

Customers are becoming more demanding and to be able to understand and predict customer's behaviour, it is necessary to identify the factors influencing the purchase of cultural products.

The aim of this research is to explore possibilities on how to manage consumer behaviour influencing factors when choosing cultural event offers. 
The main tasks of the research are: to provide an analysis of cultural and creative industry theoretical aspects, to evaluate consumer behavior influencing factors of cultural event attendance by generations in the Embassy of Latgale "GORS" and to elaborate conclusions and proposals.

Research object: consumer behaviour.

Research subject: consumer behaviour influencing factors.

Research period: 2012.-2016.

Research hypothesis: using different marketing activities depending on the distinctive types of generations is a way for attracting new customers.

Main research methods applied in the research are the monographic or descriptive research method, the Statistical Package for the Social Sciences (SPSS) processing method, the deductive method, evaluation and analysis of surveys, graphical analysis and synthesis.

Novelty of the research: it performed a consumer behaviour analysis from the generational perspective at the Embassy of Latgale "GORS".

\section{Research results \\ 1. Development trends in the cultural and creative industry}

Back in the 90ies the attempts to evaluate the socioeconomic impact of the sector of culture in economically developed countries such as the United Kingdom, the USA, Germany, France, Denmark, Australia etc. showed that the sector associated with culture or entertainment, nontraditional production structures and objects of copyright was the fastest growing sector with the greatest development potential. Cultural and creative industries have great potential for local, regional and national development as well as a significant impact on the wider economy (Heilbrun, 2001).

M. Pūkis indicates that in Latvia from the beginning of the 90ies a devious view has dominated regarding culture as the consuming sector, which did not significantly affect the economy. The cultural and creative industry affects public budgets, the public-private economy in both ways directly and indirectly (Pūksis, 2011).

In all documents and studies related to the cultural and creative industry not only in Latvia but also worldwide there are problems and difficulties to define the term "cultural and creative industries".

In Estonia creative industries, by definition, are an economic sector that is based on individual and collective creativity, skills and talent and is capable of creating welfare and jobs through the generation and use of intellectual property (Ministry of..., 2005). 
In Lithuania, creative industries are defined as activities based on an individual's creative abilities and talent, the objective and result of which is intellectual property and which can create material wellbeing and work places (Makselis, 2010).

In the United Kingdom, creative industries are defined as 'those activities which have their origin in individual creativity, skill and talent and which have a potential for wealth and job creation through the generation and exploitation of intellectual property' (Ministerial..., 2001).

In Latvia the Ministry of Culture defines cultural and creative industries as 'activities, based on individual and collective creativity, skills and talents, which by the way of generating and utilizing intellectual property are able to increase welfare and create jobs (LR Kultūras..., 2014).

Because the United Kingdom was the first which offered an original definition of creative industries (the definition developed by the British government in 1998 and updated in 2001), it has been widely adopted by other countries including Latvia, with sectors adapted based on local commercial and cultural importance (British..., 2008).

Comparing the above mentioned definitions, the author concludes that all the definitions by their nature are very similar, with minor adjustments in each of the countries examined. In the United Kingdom's and Lithuania's proposed definition, cultural and creative industries are based on individual creativity, while in the Latvian and Estonian definitions there appears the term "collective creativity", which means that not only the individual can create cultural products, but also group work based on a collective idea creates a cultural product. An example is the folk dance group where an individual dancer's talent is not as high valued as the team's value added.

The author recommends creating such a sector as cultural heritage in Latvia. In Latvia, cultural heritage as value is highly appreciated and currently not shown as a sector. It is going to promote the cultural heritage for next generations and help to strengthen national identity. The author also recommends combining television, radio and interactive media sectors into one sector. It is going to reduce the sector's fragmentation. 
Cultural and creative industries in selected countries

(The author's compilation based on LR Kultūras..., n.d., Ministry..., 2005, Makselis, 2010, Ministerial..., 2001, Directorate-General..., 2006)

\begin{tabular}{|c|c|c|c|c|c|}
\hline \multicolumn{6}{|c|}{ Country } \\
\hline \multirow{6}{*}{ 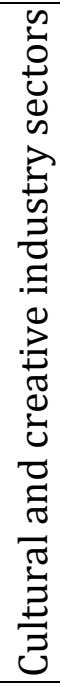 } & Latvia & Estonia & Lithuania & $\begin{array}{c}\text { United } \\
\text { Kingdom }\end{array}$ & $\begin{array}{l}\text { European } \\
\text { Union }\end{array}$ \\
\hline & Advertising & Advertising & Advertising & Advertising & Advertising \\
\hline & Architecture & Architecture & Architecture & Architecture & Architecture \\
\hline & Television & $\begin{array}{l}\text { Audiovisual } \\
\text { field }\end{array}$ & $\begin{array}{c}\text { The creation } \\
\text { and } \\
\text { broadcasting } \\
\text { of radio and } \\
\text { television } \\
\text { programmes }\end{array}$ & $\begin{array}{l}\text { Television and } \\
\text { radio }\end{array}$ & $\begin{array}{c}\text { Television and } \\
\text { radio }\end{array}$ \\
\hline & Music & Music & Music & Music & Music \\
\hline & Visual arts & Arts & Visual arts & $\begin{array}{l}\text { Designer } \\
\text { fashion }\end{array}$ & Visual arts \\
\hline & $\begin{array}{c}\text { Radio and } \\
\text { interactive arts }\end{array}$ & $\begin{array}{l}\text { Cultural } \\
\text { heritage }\end{array}$ & $\begin{array}{l}\text { Cinema and } \\
\text { video art }\end{array}$ & $\begin{array}{c}\text { The art and } \\
\text { antiques } \\
\text { market }\end{array}$ & $\begin{array}{l}\text { Cultural } \\
\text { heritage }\end{array}$ \\
\hline & Design & Design & Design & Design & Design \\
\hline & $\begin{array}{c}\text { Cultural } \\
\text { education }\end{array}$ & $\begin{array}{l}\text { Performing } \\
\text { arts }\end{array}$ & Crafts & Crafts & Video games \\
\hline & Publishing & Publishing & Publishing & Publishing & $\begin{array}{c}\text { Books and } \\
\text { press }\end{array}$ \\
\hline & $\begin{array}{c}\text { Computer games } \\
\text { and interactive } \\
\text { software }\end{array}$ & $\begin{array}{c}\text { Information } \\
\text { technology }\end{array}$ & $\begin{array}{l}\text { Software and } \\
\text { computer } \\
\text { services }\end{array}$ & $\begin{array}{c}\text { Interactive } \\
\text { leisure } \\
\text { software (i.e. } \\
\text { video games) }\end{array}$ & $\begin{array}{c}\text { PC } \\
\text { manufacturers, } \\
\text { MP3 player } \\
\text { manufacturers, } \\
\text { mobile } \\
\text { industry, etc. }\end{array}$ \\
\hline & Performing arts & - & Applied arts & Performing arts & $\begin{array}{c}\text { Performing } \\
\text { arts }\end{array}$ \\
\hline & $\begin{array}{c}\text { Recreation, } \\
\text { entertainment } \\
\text { and other } \\
\text { cultural } \\
\text { activities }\end{array}$ & - & Dramatic art & Film and video & Film and video \\
\hline & Cinematography & - & - & $\begin{array}{l}\text { Software and } \\
\text { computer } \\
\text { services }\end{array}$ & - \\
\hline
\end{tabular}


Table 2

Number of the employed in the cultural and creative sector in Latvia by industry, 2012-2014 (the author's compilation based on LR Kultūras..., 2014)

\begin{tabular}{|l|c|c|c|c|}
\hline \multirow{2}{*}{ Cultural and creative industries } & \multicolumn{3}{|c|}{ Year } \\
\cline { 2 - 5 } & 2012 & 2013 & 2014 & $\begin{array}{c}\text { Changes } \\
(2014 / 2012)\end{array}$ \\
\hline Performing arts & 7728 & 8061 & 8689 & 961 \\
\hline Heritage & 4866 & 4954 & 5060 & 194 \\
\hline Film and video & 640 & 689 & 775 & 135 \\
\hline Radio un television, the Internet & 2491 & 2653 & 2828 & 337 \\
\hline Music & 187 & 149 & 156 & -31 \\
\hline Books and press & 3699 & 3570 & 3488 & -211 \\
\hline Design & 535 & 627 & 927 & 392 \\
\hline Architecture & 2262 & 2281 & 2521 & 259 \\
\hline Advertisement & 4761 & 5240 & 5930 & 1169 \\
\hline Crafts & 661 & 689 & 747 & 86 \\
\hline Education and individual creativity & 3553 & 3685 & 3784 & 231 \\
\hline Recreation and entertainment & 9450 & 10007 & 11587 & 2137 \\
\hline Total: & $\mathbf{4 0 8 3 3}$ & $\mathbf{4 2 6 0 5}$ & $\mathbf{4 6 4 9 2}$ & $\mathbf{5 6 5 9}$ \\
\hline
\end{tabular}

Table 2 indicates that the total average number of employees in the creative and cultural sector has been growing year by year and, comparing 2014 with 2012, the number in this sector has increased by 5659 employees. The number of employees increased in all the industries, with the exception of music as well as books and press, which represents the biggest drop - 211 employees. The reason could be associated with rapid technological development. The highest rate was observed in the leisure and entertainment industry, where the number of the employed has increased by 2137 employees since 2012 . This industry generally has also the largest number of employees, whereas the smallest number is in the music industry.

The author is convinced that the cultural and creative industry's development in Latvia is influenced by the fact that primarily creative and qualified people are concentrated in large cities. In the case of Latvia, it is the capital city of Riga. That's the reason why the cultural and creative industries' development in rural areas is not so fast. But in order to develop and improve the offers of cultural activities in the regions, three concert halls were built, which are located in Cesis, Rezekne and Liepaja. The concert halls are offering a wide range of cultural events, works of art and interior objects exhibitions, as well as other creative activities. The availability of the concert halls has contributed to the cultural sector's 
development in the regions and stimulated the overall development of the Latvian economy.

\section{Evaluation of consumer behaviour-influencing factors at the Embassy of Latgale "GORS"}

To find out the factors that influence consumer behaviour and the decision-making process when choosing to attend cultural events at the Embassy of Latgale "GORS", the author conducted a survey, which involved information about respondents and nine questions. The main task of a survey as a qualitative method is to determine consumer attitude towards cultural events offered in the Embassy of Latgale "GORS", motivations, behaviour and the factors influencing the decision-making process.

The research used both direct and indirect questionnaires through the Internet. In the survey, there were collated and analyzed 253 respondents - 90 men and 163 women aged from 13 to 68 years.

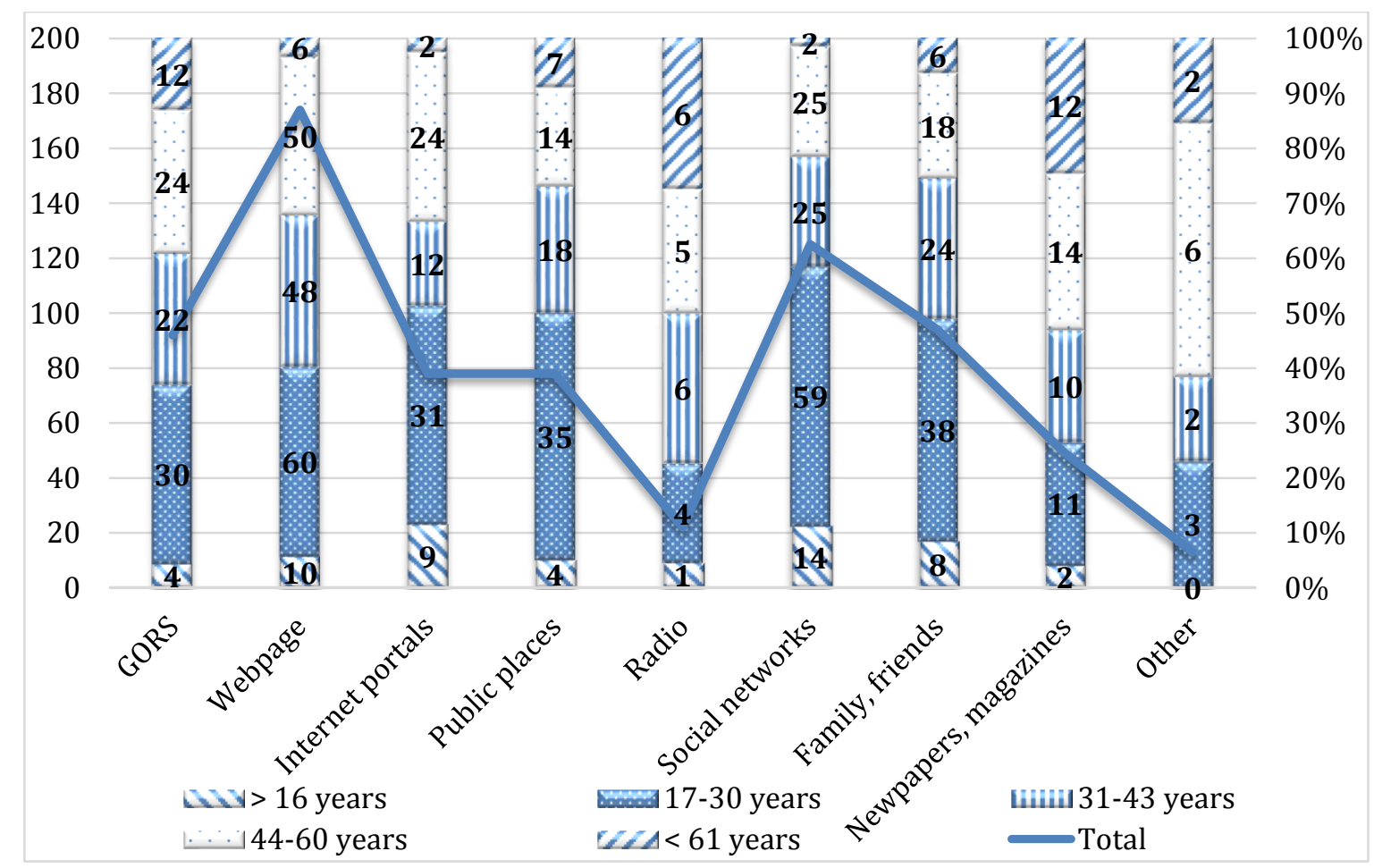

Figure 1. Information gathering channels about cultural events at the Embassy of Latgale "GORS" from the generational perspective (Source: own research)

The major channel for obtaining information about cultural events at the Embassy of Latgale "GORS" was the website - www.latgalesgors.lv, as $69 \%$ of all the respondents used this channel. Forty nine $\%$ of the respondents were using social networks, but only $9 \%$ of all the 
respondents were using radio as an information gathering channel about cultural events at the Embassy of Latgale "GORS". The respondents indicated that also TV and the websites - www.bilesuparadize.lv and www.bilesuserviss.lv were widely used as information channels.

Generation $\mathrm{Z}$ was mainly using social networks to gain information about cultural events. Generation X, Y, and Baby Boomers as the main information channel, used the website - www.latgalesgors.lv. Veterans, as the main information gathering channel, used the Information Centre at the Embassy of Latgale "GORS" and newspapers and magazines (see Figure 1).

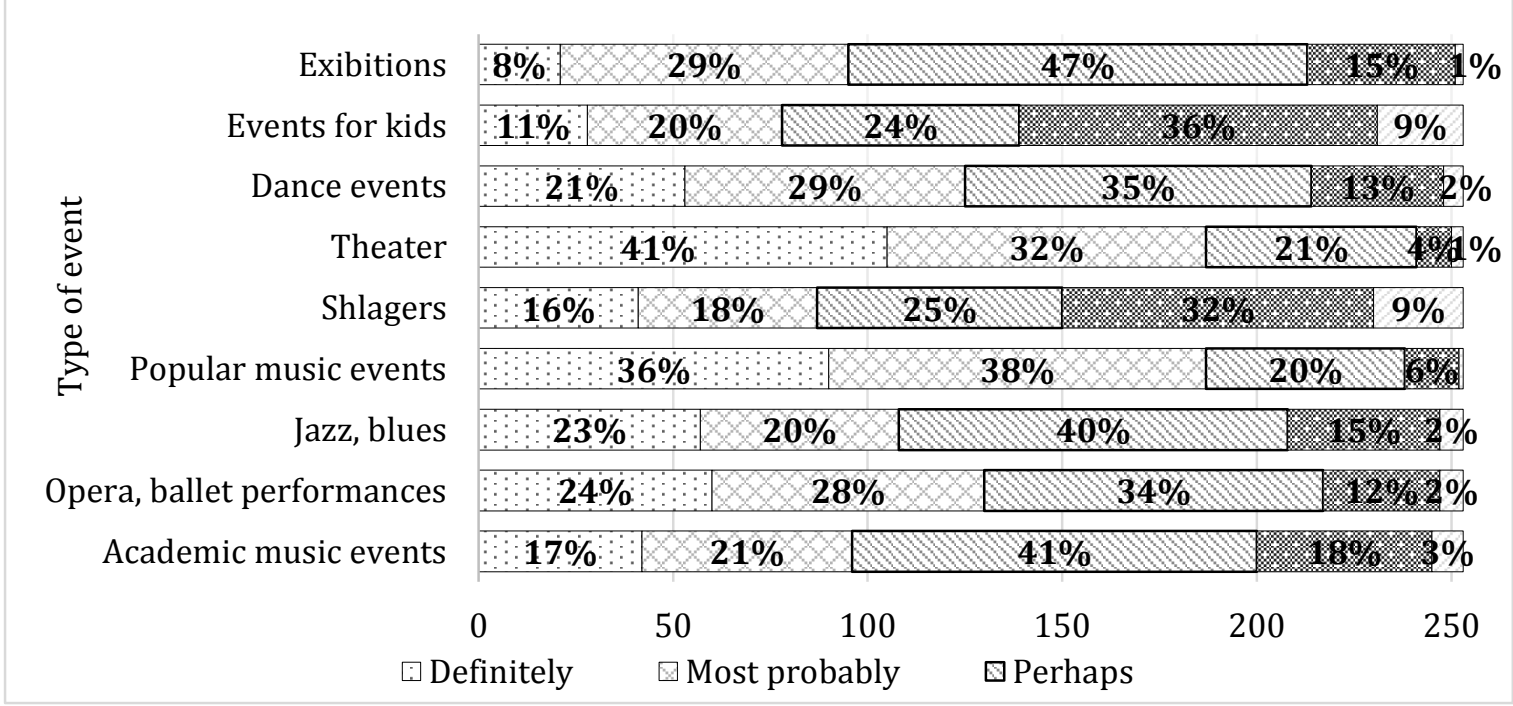

Figure 2. Attendance by type of events

(Source: own research)

Figure 2 shows that the respondents mainly attended theatre and popular music events, as $41 \%$ of the respondents noted that would definitely attend theater and $36 \%$ of all respondents will definitely attend popular music events. Only $8 \%$ of the respondents indicated that they would definitely attend exhibitions. Thirty six \% of all the respondents noted that they would not attend events for kids. This is explained by the fact that only families with kids attend this type of events. The answer "perhaps" was widely represented, which meant that this part of the audience might change their view and after a variety of marketing activities could attend cultural events. 


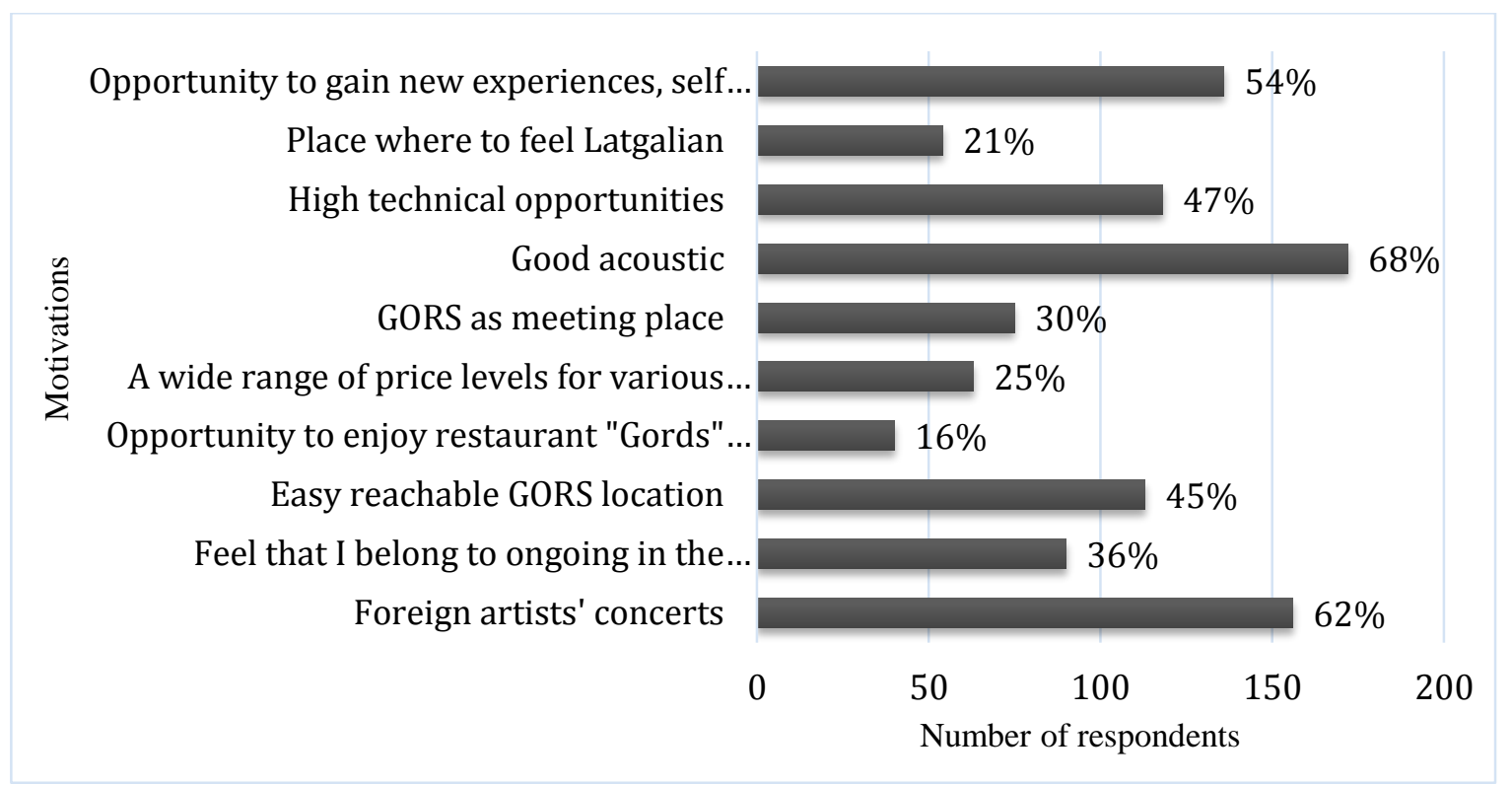

Figure 3. The main motivations to visit the Embassy of Latgale "GORS" (Source: own research)

The respondents were mostly affected by cultural factors and environmental factors. The main motivation for choosing to attend cultural events at the Embassy of Latgale "GORS" was good acoustics (68\%), which is an environmental factor. The second biggest motivation was opportunity to attend a foreign artist's concerts (62\%), which is a cultural factor. Only $16 \%$ of all the respondents noted that main motivation was opportunity to enjoy meals and drinks offered by restaurant "Gords". It means that psychological factors affect visitors the least.

Table 3

Consumer behaviour-influencing factors from the generational perspective (Source: own research)

\begin{tabular}{|c|c|c|c|c|c|c|}
\hline \multirow[b]{2}{*}{ Motivations } & \multicolumn{5}{|c|}{ Age } & \multirow{2}{*}{$\begin{array}{c}\text { Total } \\
\text { number of } \\
\text { respondents }\end{array}$} \\
\hline & $\begin{array}{l}\text { Under } \\
16, \%\end{array}$ & $\begin{array}{c}17-30 \\
\%\end{array}$ & $\begin{array}{c}31-43 \\
\%\end{array}$ & $\begin{array}{c}44-60 \\
\%\end{array}$ & $\begin{array}{c}\text { Over 61, } \\
\%\end{array}$ & \\
\hline $\begin{array}{l}\text { Opportunity to gain } \\
\text { new experience, self- } \\
\text { improvement }\end{array}$ & 77 & 54 & 49 & 55 & 40 & 136 \\
\hline $\begin{array}{l}\text { Place where to feel } \\
\text { Latgalian culture }\end{array}$ & 6 & 18 & 18 & 28 & 47 & 54 \\
\hline $\begin{array}{l}\text { High technological } \\
\text { opportunities }\end{array}$ & 65 & 41 & 51 & 42 & 67 & 118 \\
\hline Good acoustics & 65 & 70 & 71 & 58 & 93 & 172 \\
\hline $\begin{array}{l}\text { GORS as a meeting } \\
\text { place }\end{array}$ & 29 & 25 & 28 & 35 & 40 & 75 \\
\hline
\end{tabular}


Table 3 continued

\begin{tabular}{|l|r|r|r|r|r|r|}
\hline $\begin{array}{l}\text { Wide range of price } \\
\text { levels for various } \\
\text { events }\end{array}$ & 12 & 25 & 25 & 20 & 60 & 63 \\
\hline $\begin{array}{l}\text { Opportunity to enjoy } \\
\text { restaurant “Gords” } \\
\text { meals and drinks }\end{array}$ & 0 & 11 & 25 & 19 & 13 & 40 \\
\hline $\begin{array}{l}\text { Easy reachable } \\
\text { location of GORS }\end{array}$ & 18 & 46 & 48 & 44 & 60 & 113 \\
\hline $\begin{array}{l}\text { Feeling that I belong } \\
\text { to the ongoing in the } \\
\text { concert hall }\end{array}$ & 41 & 29 & 41 & 32 & 67 & 90 \\
\hline $\begin{array}{l}\text { Foreign artists' } \\
\text { concerts }\end{array}$ & 82 & 60 & 62 & 58 & 60 & 156 \\
\hline
\end{tabular}

For generation $\mathrm{Z}$ (the age group up to 16 years of age), the main motivation to attend cultural events at the Embassy of Latgale "GORS" was opportunity to attend foreign artists' concerts (82\%). No one from this generation mentioned opportunity to enjoy restaurant "Gords" meals and drinks as the main motivation. It shows that for generation $\mathrm{Z}$, the main behaviour-influencing factors were cultural factors.

For generation $Y$ (the age group from 17 to 30 years of age), the main motivation was good acoustics (70\%). Only $11 \%$ of all the respondents, as a motivation to attend culture events in the Embassy of Latgale "GORS", mentioned opportunity to enjoy restaurant "Gords" meals and drinks. It shows that for generation $Y$ the main behaviour-influencing factors were environmental factors and cultural factors.

Seventy one \% of all the respondents in the age group from 31 to 43 (generation $\mathrm{X}$ ), as the main motivation to attend the Embassy of Latgale "GORS", mentioned good acoustics. A less important motivation for this generation was the fact that the concert hall was a place where to feel Latgalian culture (18\%). It shows that for generation $\mathrm{Z}$ the main behaviour-influencing factors were cultural factors. For generation $\mathrm{X}$ the main behaviour-influencing factors were environmental factors.

Baby Boomers (the age group from 44 to 60 years of age), as the main motivations indicated good acoustics and opportunity to attend foreign artists' concerts (58\% in each statement).

For Veterans the main motivation was good acoustics (93\%), and the main behavioural-influencing factors were environmental factors.

As a less important motivation, all the generations indicated opportunity to enjoy restaurant "Gords" meals and drinks which is a psychological factor. The author concludes that psychological factors do not influence the attendance of cultural events at the Embassy of Latgale "GORS". 


\section{Conclusions and suggestions}

The main information gathering channels about culture events at the Embassy of Latgale "GORS" were the website - www.latgalesgors.lv represented by 174 respondents or $69 \%$ and social networks represented by 125 respondents or $49 \%$ of the total. This confirms the importance of the Internet as an information obtaining channel. The main behaviourinfluencing factors when choosing to attend the Embassy of Latgale "GORS" were cultural and environmental factors. Most of the respondents, as the main motivation to attend cultural events at the Embassy of Latgale "GORS" indicated good acoustics (68\% or 172 respondents) and opportunity to attend foreign artist concerts (represented by $62 \%$ or 156 respondents).

When developing marketing activities to increase the attendance of cultural events, it is important to take into account cultural event attendance from the generational perspective. This will help to better define the target audience and to select the most appropriate channels for transmitting information to each of the generations. It is important to be aware of the company's target audience and the company's aims because each of consumer generations prefers different communication channels for obtaining information about the product. It will help to reach a wider audience and more effectively manage the company's financial resources.

In Latvia the Ministry of Culture need to create such as sector as cultural heritage followed the Estonian and European Union example. In Latvia, cultural heritage as value is highly appreciated and currently not shown as a sector. Creating such as sector would help to strengthen national identity and promote the cultural heritage for the next generations. In Latvia the government needs to develop support program that would allow small businesses to offer competitive products on the market and would help to increase small business growth and development.

The hypothesis of the research was confirmed - using different marketing activities depending on the distinctive types of generations is a way to attract new customers.

\section{References}

1. British Council. (2008). What are Creative Industries and Creative Economy. Retrieved February 12, 2016, from http://creativecities.britishcouncil.org/ creative-industries/what_are_creative_industries_and_creative_economy

2. Directorate-General for Education and Culture (2006). The Economy of Culture in Europe. Brussels: KEA-European Affairs. p.355. Retrieved February 12, 2016, from http://ec.europa.eu/culture/library/studies/cultural-economy_en.pdf 
3. HEILBRUN, J., GRAY, CH. M. (2001). The Economics of Art and Culture.Cambridge: University Press. 16.p. http://catdir.loc.gov/catdir/samples/cam031/00059 875.pdf

4. LR Kultūras ministrija. (2008). Kultūras un radošās industrijas. Retrieved February 13, 2016, from http://www.km.gov.lv/lv/starpnozares/ radosas_industrijas.html

5. LR Kultūras ministrija. (2014). Statistika. Retrieved June 8, 2016, from http://www.km.gov.lv/lv/starpnozares/radosa/statistika.html

6. MAKSELIS, R. (2010). Creative industries in Estonia, Latvia and Lithuania. Tallinn:Tiiu Allikmäe. 38.p. Retrieved March 12, 2016, from http://ej.uz/a6yb

7. Ministerial Creative Industries Strategy Group. (2001). Creative Industries Mapping Documents. 21 p. Retrieved February 12, 2016, from https://www.gov.uk/government/publications/creative-industries-mappingdocuments-2001

8. Ministry of Culture in Estonia. (2005). Creative Industries. Tallinn: Ministry of Culture of Estonia. Retrieved March 14, 2016, from http://www.kul.ee/ en/activities/creative-industries

9. PŪKSIS, M. (2011). Kultūras mantojuma sociālā un ekonomiskā loma. Rīga: Valsts Kultūras piemineklu aizsardzïbas inspekcija. p. 26. Retrieved February 7, 2016, from http://mantojums.lv/_rict_text/docs/Pukis_KULTURAS_MANTOJUMS_ ekosoc_loma.pdf 


\title{
PATĒRĒTĀJU UZVEDĪBAS VADĪBAS IESPĒJU IZPĒTE KULTŪRAS UN RADOŠAJĀ NOZARĒ: LATGALES VĒSTNIECİBAS “GORS” PIEMĒRS
}

\author{
Elza JURĀNE \\ Mg. soc. sc., Latgales vēstniecība GORS, Rēzekne, Latvija
}

Kopsavilkums

Arvien vairāk pieaug interese par dažādiem kultūras pasākumiem un arvien lielāku lomu ieñem kultūras pasākuma apmeklējums, kā brīvā laika pavadīšanas veids. Kultūra tās dažādākajās izpausmēs ir mūsu ikdienas sastāvdaḷa. Kultūras pasākumu apmeklējums ir kḷuvis ne tikai par brīvā laika pavadīšanas veidu, bet arī par satikšanās vietu un iespēju socializēties. Lai spētu piedāvāt kvalitatīvi izstrādātu kultūras pasākumu programmu un sasniegtu savus klientus, ir nepieciešama patērētāju uzvedības izpēte, kas kultūras iestādēm l̦autu piedāvāt patērētāju vēlmēm atbilstošāku produktu klāstu.

Raksta mērḳis ir izpētīt iespējas vadīt patērētāju uzvedību ietekmējošos faktorus kultūras norišu piedāvājumu izvēlē.

Izvirzītā mērksa sasniegšanai ir izvirzīti šādi uzdevumi:

1. Sniegt kultūras un radošās nozares teorētisko aspektu analīzi.

2. Veikt patērētāju uzvedību ietekmējošo faktoru novērtējumu par kultūras pasākumu apmeklēšanu Latgales vēstniecībā GORS, kā arī veikt iegūto datu analīzi.

3. Izdarīt secinājumus un izstrādāt priekšlikumus par patērētāju uzvedības vadības iespējām kultūras nozarē - pasākumu piedāvājumu izvēlē.

Pēc iegūtajiem rezultātiem autore secina, ka kvalitatīvu kultūras norišu piedāvājums ne tikai palielina kultūras nozīmi Latvijā, bet arī veicina ekonomikas izaugsmi kopumā.

Svarīgākais informācijas iegūšanas kanāls par pasākumiem, kas norisinās Latgales vēstniecībā GORS ir mājaslapa - www.latgalesgors.lv, ko informācijas iegūšanai izmanto 174 respondenti jeb 69\% un sociālie tīkli, ko pārstāv 125 respondenti jeb $49 \%$ no kopēja respondentu skaita. Tas apstiprina interneta kā informācijas kanāla nozīmīgumu. Pircēju rīcību, izvēloties apmeklēt kultūras pasākumus Latgales vēstniecībā GORS, visvairāk ietekmē kultūras faktori un ārējās vides faktori.

Izstrādājot pasākumu veicināšanas aktivitātes kultūras pasākumiem, jāṇem vērā klientu apmeklējums pa dažādiem pasākuma veidiem paaudžu griezumā. Tas ḷaus veiksmīgāk noteikt pasākuma mērksauditoriju un palīdzēs izvēlēties atbilstošākos informācijas nodošanas kanālus katrai no paaudzēm. Kultūras uzñēmumiem un Latgales vēstniecības GORS mārketinga nodaḷas vadītājai ir svarīgi apzināties uzṇēmuma mērksauditoriju un to, kādus mērḳus uzṇēmums vēlas sasniegt, jo katra no patērētāju paaudzēm izvēlas atšḳirīgus komunikācijas kanālus informācijas iegūšanai par produktu. Tas l̦aus sasniegt plašāku auditoriju un efektīvāk vadīt uzn,ēmuma finanšu resursus.

Atslēgas vārdi: patērētāju uzvedība, patērētāju uzvedību ietekmējošie faktori, kultūras un radošā nozare, paaudzes. 